\title{
Mapping the Relationship among Quality Management Practices, Organizational Learning, Organizational Culture, and Organizational Performance in Higher Education: A Proposed Framework
}

\author{
Ahmed Hani Mohammed1,2, Che Azlan Bin Taib'2, Santhirasegaran a/l S.R. Nadarajan² \\ ${ }^{1}$ Industrial Management Department, University of Mosul, Mosul, Iraq \\ ${ }^{2}$ STML, COB, UUM, Kedah, Malaysia \\ Email: ahmedhani1982@gmail.com
}

Received 27 February 2016; accepted 2 April 2016; published 6 April 2016

Copyright (C) 2016 by authors and Scientific Research Publishing Inc.

This work is licensed under the Creative Commons Attribution International License (CC BY). http://creativecommons.org/licenses/by/4.0/

(c) ()

\begin{abstract}
The challenges in higher education and global competition encouraged performance excellence and the pursuit towards providing educational services characterized by high quality. To ensure performance excellence, quality management practices are considered as one of the variables that affect the organizational performance. On the other hand, organizational learning is a method that facilitates the process of improving the organizational performance. The results of organizational performance vary according to environmental conditions, especially an organizational culture that is one of the important indicators that are characterized by organizations. This encourages choosing the organizational culture as a moderating variable. However, this paper highlights organizational performance through a proposed conceptual framework to be considered in higher education institutes.
\end{abstract}

\section{Keywords}

Organizational Performance, Quality Management Practices, Organizational Learning, Organizational Culture, Higher Education Institutes

\section{Introduction}

The concept of the performance in higher education is one of the most important issues in the last decade for

How to cite this paper: Mohammed, A.H., et al. (2016) Mapping the Relationship among Quality Management Practices, Organizational Learning, Organizational Culture, and Organizational Performance in Higher Education: A Proposed Framework. American Journal of Industrial and Business Management, 6, 401-410. http://dx.doi.org/10.4236/ajibm.2016.64036 
many countries in the world for various reasons are different from one country to other [1]. At the same time, there are important factors led to an interest in the performance in higher education due to the massive expansion of higher education according to institutions or customers.

The development of economic and international society has resulted in both an expansion and the growth of new types of higher educational institutions. There was an increase in communication among these institutions and the adoption of the new rules that governed their work. The challenges of social and current reforms and economic development urge to increase research in higher education in conjunction with the effectiveness of international finance [2].

Organizational performance shows ambiguity in the findings concerning the relationship between quality management practices (QMPs) and organizational learning (OL), and several studies have investigated the relationship between QMPs and performance [3] [4]. Furthermore, other studies investigated the relationship between OL-organizational performance [5] [6]. Due to the lack of studies concerning the relationship between quality management and organizational learning and their relationship to organizational performance [7], prior surveys in literature showed several gaps that needed addressing.

Similarly, the literature dedicated to quality management revealed that the findings reported concerning the relationship between QMPs and organizational performance were obtained from a large expanse of the topic that required researching [8] [9]. While some other studies confirmed the inconsistent relationship between quality management and performance [10]. There are few studies reported failure in organizations to improve their performance. In spite of the success of quality management practices application [11], some others reported the lack of relationship between QMPs and OP [12] [13].

More importantly, organizational learning has a significant role in transforming prior experiments into novel ideas as advocated by Bapuji and Crossan [14] to transform ideas into actions and policies, with the ultimate aim of enhancing the performance of the organization [15] [16]. This boosted authors to maximize their examination and confirmation of a direct positive relationship between OL and organizational performance [17]-[22]. On the other hand, there is doubted appropriate relationship between OL and organizational performance or there is indirect relationship [7] [23]-[25].

As mentioned, researchers' findings are inconsistent to the relationship between QMPs and OL with organizational performance, this matter urged other researchers to further examine the variables and observe their impacts. In regards to this, Sharma and Gadenne [4] and Qunxiang et al. [26] stressed the importance of focusing on some organizational variables to examine the QMPs-organizational performance relationship. This has also been advocated by Wang et al. [7].

Hence, in the present study, the effect of organizational culture (OC) on the above variables' relationship is suggested in terms of achieving the optimum organizational performance. In other words, this study primarily aims to fill the gap found in the literature by suggesting the relationship between QMPs, OL and OC, and organizational performance in the context of Iraqi higher educational institutions, to examine it in future.

The remainder of this paper is structured as follows. Section 2 provides an overview of organizational performance and reviews the factors that influence organizational performance while Section 3 discusses research hypotheses. Research framework will be provided in Section 4; finally, Section 5 presents the conclusions.

\section{Overview of Organizational Performance}

Organizational performance (OP) defined by Harbour [27] through the implementation of a raft of measures that represent the final result of the activity of the organization. Due to the importance of OP and its relationship to the development of any organization, the literature showed a great deal of attention to OP and the implications of organizational effectiveness. Whereas the global competition increases the level of quality as well as quantity, this competition led to devise strategies to meet the changing needs of the customers by maintaining a high level of quality standards with seeking to reach the advanced levels in the world market. Therefore, the organizational performance depends on the quality management, through their practices, in addition to learning from leading organizations.

Additionally, the previous research focus on the important of Organizational Performance concept, through top management's success of the performance in the long term [28] [29]. The concept of OP is complex and multi-dimensional [30]. Which includes quantitative, and qualitative criteria (financial and non-financial), these standards are different according to the point view of stakeholders [31] [32], where investors assess performance in terms of returns (profits, return on investment, confidence in the capacity of management) [33]. 
Therefore, Peterson, Gijsbers [34] defined OP as "the ability of an organization to use its resources efficiently and to produce outputs that are consistent with its objectives and relevant for its users". Consistency with Antony and Bhattacharyya [35] defined OP as the measure that was used to assess and evaluate the organization success to prepare and deliver the value to its external and internal customers. In another study, de Waal and Sultan [36] determines the success of the organization's performance through the achievement of some of the financial criteria and other non-financial, during a specific period of time (e.g. five years) and this is done by focusing on the things that really interest to the organization.

The increasing competitive on organizations resulted in a greater effort to defining and measured performance, thus, ensuring that the performance concept is expanded beyond a short-term evaluation of the financial perspective and through a focus on creating value activities in a long-term (e.g. quality of internal processes, customer service, and organizational learning) [37]. That most of the studies that have been conducted to measure the performance in education sector showed the need to measure service performance, which has seen large growth and increasing global competition, where the scholars use many methods to measure the performance in higher education. Where Alexander [38] confirmed in his study that the US put an increasing burden on higher education, to increase learning skills and improve the ability of workers to the development and use of technology, thus increasing productivity. The study concluded that the perspective of economic and utilitarian values is the basis of performance measurement process because the university administration is not able to identify and demonstrate the educational goals and achievements in terms of benefit. For this noted to find ways to monitor and evaluate educational institutions scientific ways to increase the value of the resources and determine the benefit of the educational process.

Depending on OP measurements addressed by the literature, the differences in setting performance standards where some emphasized use of financial standards (e.g. return on investment, profitability), others stressed the non-financial criteria. At the same time, some others stressed combination of financial and non-financial. Many emphasized to use Balanced Scorecard (BSc), because of its comprehensive approach. In addition to benefiting from the advantages of the application of BSc in HEIs as a communication to clarify the strategic vision of the organization (including educational institutions) and teamwork, the organization's commitment to its stakeholders (beneficiaries of educational services) and their reaction to the development of performance, in addition to the learning process [39].

Since the public educational institutions are non-profit, therefore financial indicators cannot give a clear perception of real performance, considering that Not-Financial Performance Measurements (NFPMs) new global phenomenon to improve business operations and achieve long-term goals [40] [41]. In order to assess the performance and depending on the financial and non-financial perspective together, been relying on Balance scorecard (BSc) to measure internal performance in an integrated manner and for any organization. Added to this, the BCs has been extensively used in all organizations, whether profit or non-profit government [42]. For the purpose of dependence on BSc for performance measurement must identify the four perspectives of the BSc (financial, customer, internal processes, learning and growth), these perspectives work together, within the balance combination. In general, organizations depend on the financial, and customers perspective to enhancing the perspective of internal processes, and learning and growth.

However, literature supported the application of BSc in Higher Education to evaluate and plan educational programs and take advantage and the benefits of educational programs evaluation [43]-[46]. In addition to suggesting several models for the application of BSc in educational institutions such as the Umashankar and Dutta's model [44] in India and Binden, Mziu, and Suhaimi’s [47] model in Malaysian HEIs.

This study highlighted the variables that effect in organizational performance, the first one is quality management practices(QMPs) that Malcolm Baldrige National Quality Award (MBNQA) was selected as the gold standard for understanding the quality management [48], this standard content six practices [49]: Leadership, Strategic planning, Workforce, Customer focus, Information and Analysis, process management. As well as determine the effect of organizational learning [22], in addition to the role of organizational culture as a variable moderating [50].

\section{Research Hypotheses Development}

\subsection{The Relationship between Quality Management Practices and Organizational Performance}

Many studies have focused on quality management practices [51] [52]. As well as, the literature has produced a 
lot of studies that have examined the relationship between quality management practices, and organizational performance. These studies conflicted results. Some studies have a direct relationship between the two variables [3] [4], and other indirect [53] [54], as well as, few studies reject the relationship [12] [13]. According to the previous literature, the hypothesis is:

H1: Quality management practices have a significant effect on the organizational performance.

\subsection{Relationship between Organizational Learning and Organizational Performance}

Organizations seeking to excellence, especially with the intense competition, for that confirmed the organizations to look for the factors affecting the organizational performance. One factor that affects performance is organizational learning, through increased productivity and experience [5] [55] [56]. According to the study Lopez, Peón [22], which explained that some evidence supporting the relationship between organizational learning and performance, due to the lack of quantitative studies and reliance on case studies could not be generalized results, and others need to test empirically [57].

Previous studies that examined the relationship between organizational learning and performance many relationships indicated. Including direct relationship [19]-[21] [58]-[60], others indirect or not significant direct relationship [6] [7] [23] [24]. From another side, there are some studies proposed the relationship between organizational learning and performance without proving it empirically [61]-[63]. Base of previous literature the hypothesis as following:

H2: There are positive direct effects of organizational learning on organizational performance.

\subsection{Moderating Effect of Organizational Culture between Quality Management Practices and Organizational Performance}

Organizational culture (OC) has been studied as an important determinant in the organizational performance field [50] [64]-[66]. For focus to the relation between organizational culture and organizational performance, there are many studies related to this relation such as Imam, Abbasi [67] study that examines the OC effect with organizational performance in higher education institutes (HEIs), and the relation is significant. In a similar study, the relationship between OC and performance has examined in industrial organizations this study has been proven the strength and significant relation between the variables [68]. In addition to many other studies that described the relationship between OC and performance of "significant relationship" such as [69] [70], and some other study proposed theory link [65] [71]-[73]. Although there are some studies which finding lack relationship (not significant) between culture and performance or indirectly relationship such as [74] [75], However, most studies tend toward the positive relationship, and this sense the study is based on using OC as a moderating variable, which is expressed by Baron and Kenny [76] through the definition of a moderator variable as "a qualitative or quantitative variable that affects the direction and/or strength of the relation between an independent and dependent or criterion variable".

From another side, literature showed the importance of organizational culture in quality management practices, and it seems clear, according to Detert et al.'s [77] study, negligence of culture causes failure of previous efforts of quality, as a result, there are difficulties to accept changes within the organization, to compatible with the environment through quality management practices. However, there are studies focus on the relation between Quality practices and OC such as [78] [79], In order to point out the importance of OC as an influence on the relationship between QMPs and organizational performance, Zhang and Wu [80] has tested the effect of national culture on the relationship between QMPs and performance, in eight countries around the world, the study proved that there is a positive relationship between the practices and culture that are influencing factor in raising performance. Which were in line with a previous study has adopted the role of culture and its impact on practices to get higher performance compared with other organizations [81]. Moreover, Karimi and Kadir [82] examine the effect of OC with soft and hard TQM, this study find a significant relation between some OC dimensions and no significant with others dimensions. Based on the previous studies, the hypothesis is:

H3: Organizational culture moderates the relationship between quality management practices and organizational performance.

\subsection{Moderating Effect of Organizational Culture between Organizational Learning and Organizational Performance}

The literature indicated the existence of a relationship between organizational performance and OC, and to de- 
termine the role of OC in organizational learning should be reviewed studies, which focused on testing the relationship between them. Therefore notice Doktor, Bangert [83] to the importance of attention to the culture when determining organizational learning processes at the global level. In line with the literature, which addressed examined the relationship between OC and organizational learning, Pool [84] concluded in his study, the relationship between OC and organizational learning directly and significant, and agreed with other studies such as [85] [86]. On the other hand, Zhang et al. [86] studied the relationship between OC and organizational learning on teamwork level.

Finally, Li et al. [59] study showed a positive relationship among OC, organizational performance and learning. As well as, Rebelo and Duarte Gomes [88] mention for strengthening organization success is the result of OC orientation towards organizational learning. This result is consistent with a previous study conducted by López et al. [89] to measure organizational Performance in Spanish factories, which produced a positive relationship between OC and organizational learning with performance. Depending on the review of relations among OC, organizational learning and performance can be hypothesis as following:

H4: Organizational culture moderates the relationship between organizational learning and organizational performance.

\subsection{Moderating Effect of Organizational Culture among Quality Management Practice, Organizational Learning and Organizational Performance}

Depending on previous studies, the relationships among quality management practices, quality management practices, organizational learning, and organizational culture, with the organizational performance are studied. The study proposed to integrate the relationship between all the variables as follows:

H5: Organizational culture moderates the relationship among quality management practices, organizational learning and organizational performance.

\section{Research Framework and Methodology}

The concept of theoretical framework is that the framework illustrates the relationship between the variables in this study [90]. The development of the theoretical framework is done after reviewing of literature on Quality management practice, organizational learning, organizational culture, and organizational performance.

In order to improve the measurement method the relationship among the variables, since the variables of the study considered an organization variable, the study suggests choosing the "head of departments" in the university as a responder to questionnaire. In addition to using Partial Least Squares -Structural Equation Modeling (PLS-SEM) to measuring the moderator effect to the relation.

Based on the previous discussion in the literature and hypotheses development, there are two independent variables Table 1, quality management practice and organizational learning effect to dependent variable that organizational performance, by organizational culture as a moderation variable. As well as, the details of this relation are illustrated in Figure 1.

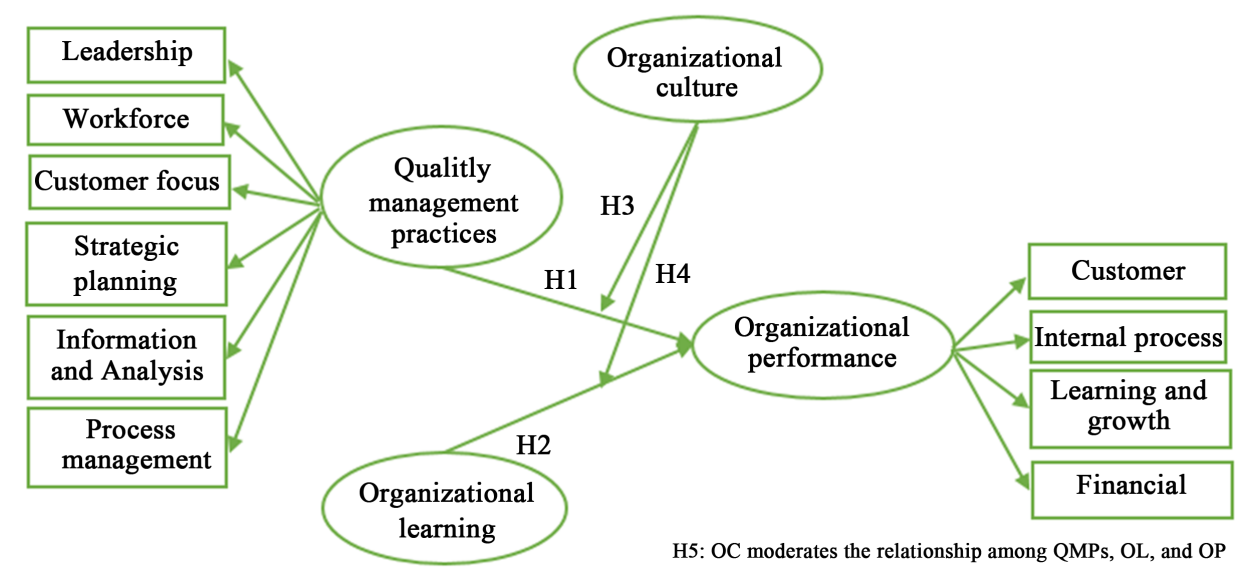

Figure 1. Conceptual framework. 
Table 1. Description of the research variables.

\begin{tabular}{ccc}
\hline Independent Variables & Moderating Variable & Dependent Variable \\
\hline Quality management practices & Organizational culture & Organizational performance \\
Organizational learning & & \\
\hline
\end{tabular}

Consequently, the idea of this paper does not contradict with the previous literature, however, the proposed conceptual framework of this paper provides an introduction to the different variables which affect the organizational performance in higher education. QMPs which proposed as independent variables (dependent on MBNQA factors) are: Leadership, Workforce, Customer focus, Strategic planning, Information and analysis, and Process management. As well as, the second independent variable is organizational learning. In addition, organizational culture is proposed as a moderator variable.

\section{Conclusion}

The evidence from the previous studies has shown that success of organizational performance is dependent on the extent of its commitment to quality management practices, organizational learning, and organizational culture. Figure 1 performs theoretical model on the relationship of quality management practices, organizational learning, organizational culture, and organizational performance. The proposed model describes the relationship among the constructs. The model in this study will give a comprehensive understanding of the direct and indirect effects on the relationship among these variables to support this model through testing the hypothesis empirically in the future.

\section{References}

[1] Masri, S. and Wilkens, K. (2011) Higher Education Reform in the Arab World. The Brookings Project on US Relations with the Islamic World, Washington DC.

[2] Abankina, I., Abankina, T., Filatova, L., Nikolayenko, E. and Seroshtan, E. (2012) The Effects of Reform on the Performance of Higher Education Institutions. Journal of Applied Research in Higher Education, 4, 23-41. http://dx.doi.org/10.1108/17581181211230612

[3] Ng, K.S. and Jantan, M. (2010) Quality Management Practices in Malaysia: Perceived Advancement in Quality Management and Business Performance. In: Proceedings of the 2010 IEEE International Conference on Management of Innovation and Technology (ICMIT), Singapore, 2-5 June 2010, 263-268.

[4] Sharma, B. and Gadenne, D. (2010) Entry Barriers and Industry Rivalry: Do They Mediate the Relationship between Quality Management Practices and Performance? International Journal of Quality \& Reliability Management, 27, 779793. http://dx.doi.org/10.1108/02656711011062381

[5] Guinot, J., Chiva, R. and Mallén, F. (2015) The Effects of Altruism and Relationship Conflict on Organizational Learning. International Journal of Conflict Management, 26, 85-112. http://dx.doi.org/10.1108/IJCMA-12-2013-0100

[6] Pokharel, M.P. and Choi, S.O. (2015) Exploring the Relationships between the Learning Organization and Organizational Performance. Management Research Review, 38, 126-148. http://dx.doi.org/10.1108/MRR-02-2013-0033

[7] Wang, X.N., Tian, Y.Z., Cheng, Y.J., Li, C.H. and Hao, Y.Q. (2011) The Relationship among Organizational Learning, Quality Method Integration and Performance. In: 2011 International Conference on Business Management and Electronic Information (BMEI), Guangzhou, 13-15 May 2011, 57-60.

[8] Bozbura, T., Bayraktar, E. and Tatoglu, E. (2011) A Causal Model of Quality Management Practices and Stakeholder Interests in Higher Education Institutions: Comparison of Public and Private Universities. In: 2011 Proceedings of PICMET'11, Technology Management in the Energy Smart World (PICMET), Portland, 31 July-4 August 2011, 1-12.

[9] Nair, A. (2006) Meta-Analysis of the Relationship between Quality Management Practices and Firm PerformanceImplications for Quality Management Theory Development. Journal of Operations Management, 24, 948-975. http://dx.doi.org/10.1016/j.jom.2005.11.005

[10] Carter, R.E., Lonial, S.C. and Raju, P. (2010) Impact of Quality Management on Hospital Performance: An Empirical Investigation. Quality Management Journal, 17, 8-24.

[11] Sabella, A.R., et al. (2014) Quality Management Practices and Their Relationship to Organizational Performance. International Journal of Operations \& Production Management, 34, 1487-1505.

[12] Yeung, A.C.L., Cheng, T.C.E. and Lai, K. (2006) An Operational and Institutional Perspective on Total Quality Management. Production and Operations Management, 15, 156-170. 
[13] Mohrman, S.A., et al. (1995) Total Quality Management: Practice and Outcomes in the Largest US Firms. Employee Relations, 17, 26-41. http://dx.doi.org/10.1108/01425459510086866

[14] Bapuji, H. and Crossan, M. (2004) From Questions to Answers: Reviewing Organizational Learning Research. Management Learning, 35, 397-417. http://dx.doi.org/10.1177/1350507604048270

[15] Argote, L. (2012) Organizational Learning: Creating, Retaining and Transferring Knowledge. Springer Science \& Business Media, Berlin.

[16] Lipshitz, R., Friedman, V. and Popper, M. (2006) Demystifying Organizational Learning. Sage Publications, Sage Publications.

[17] Ni, W.B. (2006) Relationship between Information Technology, Organizational Learning and Performance: An Empirical Study in State-Owned Firms in China. 2006 IEEE International Conference on Management of Innovation and Technology, Singapore, 21-23 June 2006, 508-512. http://dx.doi.org/10.1109/ICMIT.2006.262233

[18] Wu, C.-H., Wang, S.-L. and Fang, K. (2007) The Effect of Organization Process Focus and Organizational Learning on Project Performance: An Examination of Taiwan's Companies. Portland International Center for Management of Engineering and Technology, Portland, 5-9 August 2007, 1083-1089. http://dx.doi.org/10.1109/picmet.2007.4349429

[19] Zhang, L., Jia, Q. and Li, P. (2008) An Empirical Study on the Structure of Organizational Learning and Organizational Performance. 8th IEEE International Conference on Advanced Learning Technologies, Santander, 1-5 July 2008, 189-193. http://dx.doi.org/10.1109/icalt.2008.72

[20] Wang, Y. and Zhu, Y. (2009) Strategical Role of Organizational Learning and Knowledge Sharing on Relationship between Human Resource Management System and Performance. International Conference on Management and Service Science, Wuhan, 20-22 September 2009, 1-4. http://dx.doi.org/10.1109/icmss.2009.5305178

[21] Zhang, L. (2011) An Empirical Study on the Moderating Effect of Entrepreneurial Cognitive Biases on the Relationship between Organizational Learning and Firm Performance-Data from Minnan Region in Fujian Province in China. International Conference on Business Management and Electronic Information (BMEI), Guangzhou, 13-15 May 2011, 592-595. http://dx.doi.org/10.1109/icbmei.2011.5917981

[22] Lopez, S.P., Peón, J.M.M. and Ordás, C.J.V. (2005) Organizational Learning as a Determining Factor in Business Performance. The Learning Organization, 12, 227-245. http://dx.doi.org/10.1108/09696470510592494

[23] Chen, J., Liu, Z.-C. and Wu, N.-Q. (2009) Relationships between Organizational Learning, Innovation and Performance: An Empirical Examination. International Conference on Information Management, Innovation Management and Industrial Engineering, Xi'an, 26-27 December 2009, 488-492. http://dx.doi.org/10.1109/iciii.2009.427

[24] Liu, J.-Y. (2010) A Study on the Relationship of Organizational Learning, Strategic Change and Organizational Performance. International Conference on Management Science and Engineering (ICMSE), Melbourne, 24-26 November 2010, 470-476. http://dx.doi.org/10.1109/icmse.2010.5719846

[25] Yin, C. (2013) Does the External Knowledge Environment Matter? A Study on Firms' Learning Processes and Performance under Different Knowledge Environmental Conditions. International Conference on Management Science and Engineering (ICMSE), Harbin, 17-19 July 2013, 1349-1354.

[26] Zhang, Q., Xiong, W. and Feng, X. (2010) Exploring the Mechanism of How Quality Management Practices Impact on Firm Performance: A Theoretical Framework. 2nd International Conference on e-Business and Information System Security (EBISS), Wuhan, 22-23 May 2010, 1-5. http://dx.doi.org/10.1109/ebiss.2010.5473605

[27] Harbour, J.L. (2008) The Performance Paradox: Understanding the Real Drivers That Critically Affect Outcomes. CRC Press, Boca Raton.

[28] Reger, R.K. (1997) Strategic Leadership: Top Executives and Their Effects on Organizations. Academy of Management Review, 22, 802-805. http://dx.doi.org/10.2307/259414

[29] Finkelstein, S. and Hambrick, D. (1996) Strategic Leadership: Top Executives and Their Effects on Organizations. West Publishing Company, St. Paul, Minneapolis.

[30] Prieto, I.M. and Revilla, E. (2006) Learning Capability and Business Performance: A Non-Financial and Financial Assessment. The Learning Organization, 13, 166-185. http://dx.doi.org/10.1108/09696470610645494

[31] Rhee, J., Park, T. and Lee, D.H. (2010) Drivers of Innovativeness and Performance for Innovative SMEs in South Korea: Mediation of Learning Orientation. Technovation, 30, 65-75. http://dx.doi.org/10.1016/j.technovation.2009.04.008

[32] Espinosa, A. and Porter, T. (2011) Sustainability, Complexity and Learning: Insights from Complex Systems Approaches. The Learning Organization, 18, 54-72. http://dx.doi.org/10.1108/09696471111096000

[33] Hubbard, G. (2009) Measuring Organizational Performance: Beyond the Triple Bottom Line. Business Strategy and the Environment, 18, 177-191. http://dx.doi.org/10.1002/bse.564

[34] Peterson, W., Gijsbers, G. and Wilks, M. (2003) An Organizational Performance Assessment System for Agricultural Research Organizations: Concepts, Methods, and Procedures. ISNAR Research Management Guidelines No. 7, International Service for National Agricultural Research, The Hague. 
[35] Antony, J.P. and Bhattacharyya, S. (2010) Measuring Organizational Performance and Organizational Excellence of SMEs-Part 2: An Empirical Study on SMEs in India. Measuring Business Excellence, 14, 42-52. http://dx.doi.org/10.1108/13683041011074209

[36] de Waal, A. and Sultan, S. (2012) Applicability of the High Performance Organization Framework in the Middle East: The Case of Palestine Polytechnic University. Education, Business and Society: Contemporary Middle Eastern Issues, 5, 213-223. http://dx.doi.org/10.1108/17537981211265598

[37] Kaplan, R.S. and Norton, D.P. (1996) Using the Balanced Scorecard as a Strategic Management System. Harvard Business Review, 74, 75-85.

[38] Alexander, F.K. (2000) The Changing Face of Accountability: Monitoring and Assessing Institutional Performance in Higher Education. The Journal of Higher Education, 71, 411-431. http://dx.doi.org/10.2307/2649146

[39] Wang, G., Wan, J. and Zhao, L. (2014) Strategy Map for Chinese Science Parks with KPIs of BSC. Journal of Science and Technology Policy Management, 5, 82-105. http://dx.doi.org/10.1108/JSTPM-01-2014-0003

[40] Ittner, C.D. and Larcker, D.F. (2003) Coming up Short on Nonfinancial Performance Measurement. Harvard Business Review, 81, 88-95.

[41] Liedtka, S.L., Church, B.K. and Ray, M.R. (2008) Performance Variability, Ambiguity Intolerance, and Balanced Scorecard-Based Performance Assessments. Behavioral Research in Accounting, 20, 73-88. http://dx.doi.org/10.2308/bria.2008.20.2.73

[42] Kaplan, R.S. and Norton, D.P. (2001) Transforming the Balanced Scorecard from Performance Measurement to Strategic Management: Part I. Accounting Horizons, 15, 87-104. http://dx.doi.org/10.2308/acch.2001.15.1.87

[43] Karpagam, U. and Suganthi, L. (2012) A Strategy Map of Balanced Scorecard in Academic Institutions for Performance Improvement. IUP Journal of Business Strategy, 9, 7-16.

[44] Umashankar, V. and Dutta, K. (2007) Balanced Scorecards in Managing Higher Education Institutions: An Indian Perspective. International Journal of Educational Management, 21, 54-67. http://dx.doi.org/10.1108/09513540710716821

[45] Farid, D., Mirfakhredini, H. and Nejati, M. (2008) Prioritizing Higher Education Balanced Scorecard Performance Indicators Using Fuzzy Approach in an Iranian Context. Lex ET Scientia International Journal, 15, 338-349.

[46] Kassahun, T. (2010) Rethinking Institutional Excellence in Ethiopia: Adapting and Adopting the Balanced Scorecard (BSC) Model. Journal of Business and Administrative Studies, 2, 22-53.

[47] Binden, W., Mziu, H. and Suhaimi, M.A. (2014) Employing the Balanced Scorecard (BSC) to Measure Performance in Higher Education-Malaysia. International Journal of Information and Communication Technology Research, 4, 3844.

[48] Dew, J.R. (2009) Quality Issues in Higher Education. Journal for Quality and Participation, 32, 4-9.

[49] NIST (2015) About MBNQA. http://www.nist.gov/baldrige/about/index.cfm

[50] Denison, D.R. and Mishra, A.K. (1995) Toward a Theory of Organizational Culture and Effectiveness. Organization Science, 6, 204-223. http://dx.doi.org/10.1287/orsc.6.2.204

[51] Laohavichien, T., Fredendall, L.D. and Cantrell, R.S. (2011) Leadership and Quality Management Practices in Thailand. International Journal of Operations \& Production Management, 31, 1048-1070. http://dx.doi.org/10.1108/01443571111172426

[52] Singh, L.P., Bhardwaj, A. and Sachdeva, A. (2006) Quality Management Practices vs. Performance of SMEs: An Empirical Study of Indian Industries. PICMET 2006 Technology Management for the Global Future, Istanbul, 8-13 July 2006, 2393-2399. http://dx.doi.org/10.1109/PICMET.2006.296826

[53] Su, Q., Li, Z., Zhang, S.-X., Liu, Y.-Y. and Dang J.-X. (2008) The Impacts of Quality Management Practices on Business Performance: An Empirical Investigation from China. International Journal of Quality \& Reliability Management, 25, 809-823. http://dx.doi.org/10.1108/02656710810898621

[54] Laosirihongthong, T., Teh, P.-L. and Adebanjo, D. (2013) Revisiting Quality Management and Performance. Industrial Management \& Data Systems, 113, 990-1006. http://dx.doi.org/10.1108/IMDS-02-2013-0058

[55] Argote, L. and Miron-Spektor, E. (2011) Organizational Learning: From Experience to Knowledge. Organization Science, 22, 1123-1137. http://dx.doi.org/10.1287/orsc.1100.0621

[56] Chiva, R. and Alegre, J. (2009) Organizational Learning Capability and Job Satisfaction: An Empirical Assessment in the Ceramic Tile Industry. British Journal of Management, 20, 323-340. http://dx.doi.org/10.1111/j.1467-8551.2008.00586.x

[57] Ho, T.C.F., Ahmad, N.H. and Thurasamy, R. (2013) Learn and Thou Shall Thrive: Advancing a Model of Workplace Familism and Organizational Learning Capability in Small and Medium Enterprise (SMEs) Manufacturers in Malaysia. Business Strategy Series, 14, 151-159. http://dx.doi.org/10.1108/BSS-08-2012-0045 
[58] Hooi, L.W. and Ngui, K.S. (2014) Enhancing Organizational Performance of Malaysian SMEs: The Role of HRM and Organizational Learning Capability. International Journal of Manpower, 35, 973-995. http://dx.doi.org/10.1108/IJM-04-2012-0059

[59] Li, D.-Q., Surname, J. and Surname, P.M. (2006) Organizational Culture, Learning Capability and Firm Performance: An Empirical Study. International Conference on Management Science and Engineering, Lille, 5-7 October 2006, 1406-1411. http://dx.doi.org/10.1109/icmse.2006.314250

[60] Yang, J. and Lan, H. (2010) The Moderating Role of Organizational Learning in the Relationship between Organizational Innovation and Performance. 2010 International Conference on Management and Service Science, Wuhan, 24-26 August 2010, 1-4. http://dx.doi.org/10.1109/icmss.2010.5577016

[61] Alavi, S., Wahab, D.A. and Muhamad, N. (2010) Exploring the Relation between Organizational Learning and Knowledge Management for Improving Performance. 2010 International Conference on Information Retrieval \& Knowledge Management (CAMP), Shah Alam, 17-18 March 2010, 297-302. http://dx.doi.org/10.1109/INFRKM.2010.5466899

[62] Zheng, X. and Cui, Y. (2007) Entrepreneurial Orientation, Market Orientation and Firm Performance: The Mediator Role of Organizational Learning. International Conference on Wireless Communications, Networking and Mobile Computing, Shanghai, 21-25 September 2007, 4391-4394. http://dx.doi.org/10.1109/wicom.2007.1083

[63] Carnes, W.E. and Breslau, B. (2002) Lessons Learned: Improving Performance through Organizational Learning. Proceedings of the 2002 IEEE 7th Conference on Human Factors and Power Plants, 2002, 2-23-2-27. http://dx.doi.org/10.1109/hfpp.2002.1042829

[64] Hofstede, G., et al. (1990) Measuring Organizational Cultures: A Qualitative and Quantitative Study across Twenty Cases. Administrative Science Quarterly, 35, 286-316. http://dx.doi.org/10.2307/2393392

[65] Abu-Jarad, I.Y., Yusof, N. and Nikbin, D. (2010) A Review Paper on Organizational Culture and Organizational Performance. International Journal of Business and Social Science, 1, 26-46.

[66] Lim, B. (1995) Examining the Organizational Culture and Organizational Performance Link. Leadership \& Organization Development Journal, 16, 16-21. http://dx.doi.org/10.1108/01437739510088491

[67] Imam, A., et al. (2013) Organizational Culture and Performance of Higher Educational Institutions: The Mediating Role of Individual Readiness for Change. European Journal of Business and Management, 5, 23-34.

[68] Quan, X.-Y. (2006) Exploring Sustained Competitive Advantage: The Effect of Organizational Culture on Firm Performance. International Conference on Management Science and Engineering, Lille, 5-7 October 2006, 1372-1377. http://dx.doi.org/10.1109/icmse.2006.314244

[69] Acar, A.Z. and Acar, P. (2014) Organizational Culture Types and Their Effects on Organizational Performance in Turkish Hospitals. EMAJ: Emerging Markets Journal, 3, 18-31. http://dx.doi.org/10.5195/emaj.2014.47

[70] Ehtesham, U.M., Muhammad, T.M. and Muhammad, S.A. (2011) Relationship between Organizational Culture and Performance Management Practices: A Case of University in Pakistan. Journal of Competitiveness, 1, 78-86.

[71] Shahzad, F., et al. (2012) Impact of Organizational Culture on Organizational Performance: An Overview. Interdisciplinary Journal of Contemporary Research in Business, 3, 975-985.

[72] Aftab, H., Rana, T. and Sarwar, A. (2012) An Investigation of the Relationship between Organizational Culture and the Employee's Role Based Performance: Evidence from the Banking Sector. International Journal of Business \& Commerce, 2, 1-13.

[73] Ilieş, L. and Gavrea, C. (2008) The Link between Organizational Culture and Corporate Performance-An Overview. Annals of Faculty of Economics, 4, 322-329.

[74] Yesil, S. and Kaya, A. (2013) The Effect of Organizational Culture on Firm Financial Performance: Evidence from a Developing Country. Procedia-Social and Behavioral Sciences, 81, 428-437. http://dx.doi.org/10.1016/j.sbspro.2013.06.455

[75] Hilman, H. and Siam, M. (2014) The Influence of Organizational Structure and Organization Culture on the Organizational Performance of Higher Educational Institutions: The Moderating Role of Strategy Communication. Asian Social Science, 10, 142. http://dx.doi.org/10.5539/ass.v10n13p142

[76] Baron, R.M. and Kenny, D.A. (1986) The Moderator-Mediator Variable Distinction in Social Psychological Research: Conceptual, Strategic, and Statistical Considerations. Journal of Personality and Social Psychology, 51, 1173-1182. http://dx.doi.org/10.1037/0022-3514.51.6.1173

[77] Detert, J.R., Schroeder, R.G. and Mauriel, J.J. (2000) A Framework for Linking Culture and Improvement Initiatives in Organizations. Academy of Management Review, 25, 850-863.

[78] Sinha, N., Garg, A.K. and Dhall, N. (2012) Inter Linkages between Organizational Culture and Quality Management System: A Study of Small and Medium Enterprises in Indian Auto Component Sector. DIAS Technology Review, 9, 27-36. 
[79] do Nascimento Gambi, L., Gerolamo, M.C. and Carpinetti, L.C.R. (2013) A Theoretical Model of the Relationship between Organizational Culture and Quality Management Techniques. Procedia-Social and Behavioral Sciences, 81, 334-339. http://dx.doi.org/10.1016/j.sbspro.2013.06.438

[80] Zhang, D. and Wu, S.J. (2014) The Focus of Quality Management Practices: A National Culture Perspective. International Journal of Business and Management, 9, 91-102. http://dx.doi.org/10.5539/ijbm.v9n2p91

[81] Wu, S.J., Zhang, D. and Schroeder, R.G. (2011) Customization of Quality Practices: The Impact of Quality Culture. International Journal of Quality \& Reliability Management, 28, 263-279. http://dx.doi.org/10.1108/02656711111109883

[82] Karimi, Y. and Kadir, S.L.S.A. (2012) The Impact of Organisational Culture on the Implementation of TQM: Empirical Study in the Iranian Oil Company. American Journal of Industrial and Business Management, 2, 205-216. http://dx.doi.org/10.4236/ajibm.2012.24027

[83] Doktor, R., Bangert, D. and Valdez, M. (2005) Organizational Learning and Culture in the Managerial Implementation of Clinical e-Health Systems: An International Perspective. Proceedings of the 38th Annual Hawaii International Conference on System Sciences, 3-6 January 2005, 145c.

[84] Pool, S.W. (2000) The Learning Organization: Motivating Employees by Integrating TQM Philosophy in a Supportive Organizational Culture. Leadership \& Organization Development Journal, 21, 373-378. http://dx.doi.org/10.1108/01437730010379276

[85] Shoid, M.S.M. and Kassim, N.A. (2012) Organizational Culture and Teamwork Cooperation as Determinants of Organizational Learning Capabilities (OLC) in Academic Library. IEEE Symposium on Business, Engineering and Industrial Applications, Bandung, 23-26 September 2012, 274-278.

[86] Vijayakumar, V. and Padma, R. (2014) Impact of Perceived Organizational Culture and Learning on Organizational Identification. International Journal of Commerce and Management, 24, 40-62. http://dx.doi.org/10.1108/IJCoMA-01-2012-0003

[87] Zhang, Z., Gong, L., Xiao, Y. and Xie, J. (2013) Research on the Influence of Team Culture on Team Learning. 6th International Conference on Information Management, Innovation Management and Industrial Engineering (ICIII), Xi’an, 23-24 November 2013, 127-130. http://dx.doi.org/10.1109/iciii.2013.6703099

[88] Rebelo, T.M. and Duarte Gomes, A. (2011) Conditioning Factors of an Organizational Learning Culture. Journal of Workplace Learning, 23, 173-194. http://dx.doi.org/10.1108/13665621111117215

[89] López, S.P., Peón, J.M.M. and Ordás, C.J.V. (2004) Managing Knowledge: The Link between Culture and Organizational Learning. Journal of Knowledge Management, 8, 93-104. http://dx.doi.org/10.1108/13673270410567657

[90] Sekaran, U. (2000) Research Methods for Business: A Skill Business Approach. John Wiley \& Sons, New York. 